\title{
PERKEMBANGAN ANAK DITINJAU DARI KEMAMPUAN SOSIAL EMOSIONAL
}

\author{
Oleh. \\ M. Arif Khoiruddin \\ arif.khoiruddin84@gmail.com \\ Institut Agama Islam Tribakti Kediri
}

\section{Abstrak}

Perkembangan anak merupakan fase yang sangat penting, kritis serta memiliki pengaruh besar pada kehidupan selanjutnya. Usia 6 hingga 11 tahun adalah masa pertumbuhan dan perkembangan anak tidak hanya secara fisik tetapi juga perkembangan sosial dan emosional mereka. Peran orang tua terhadap perkembangan anak sangat signifikan, keluarga adalah media pertama setelah lingkungan sekolah dan kemudian di masyarakat. Perkembangan sosial emosinal anak adalah faktor yang sangat penting dan perlu dipertimbangkan, ketika perkembangan emosional terhambat, perkembangan sosial dapat berpengaruh. Anak-anak dengan masalah perkembangan sosial emosional cenderung memiliki hambatan besar dalam persahabatan, penyesuaian sosial, perilaku dan akademis, gangguan dianggap berisiko tersisih secara sosial, terisolasi, penarikan diri, rasa malu dan kesepian. Suasana kekeluargaan atau lingkungan yang nyaman, tenang, dan penuh pengertian, akan membuat anak berkembang dengan ceria, lincah dan bersemangat. Kemampuan berpikir juga akan berkembang dengan baik. Sebaliknya, orang tua atau pengasuh yang sering mengkritik, memarahi dan memukul anak, akan menyebabkan perkembangan sosial emosional negatif.

Kata Kunci: Perkembangan, Anak, Sosial, Emosi 


\section{Pendahuluan}

Perkembangan anak sangat penting dan berpengaruh besar dalam kehidupan manusia. Masa anak dibagi menjadi dua, pertama masa awal yaitu perkembangan dari berakhirnya masa bayi usia 5 atau 6 tahun, kedua masa menengah atau akhir saat anak usia 6 hingga 11 tahun. ${ }^{1}$ Selama masa pertumbuhan dan perkembangan, anak tidak hanya tumbuh secara fisik tetapi juga berkembang secara mental dan sosial. Pada masa ini bagi orang tua merupakan kesempatan emas untuk merangsang pertumbuhan dan perkembangannya, pada masa ini pula rentan berbagai macam bahaya yang mengganggu pertumbuhan dan perkembangan. $^{2}$

Hasil penelitian menunjukkan bahwa peran orang tua dalam perkembangan anak sangat signifikan jika orang tua terlibat aktif dalam proses pengasuhan dan pendidikannya. Anak akan menunjukkan peningkatan prestasi belajar yang diikuti oleh peningkatan sikap, stabilitas sosial emosional serta kedisiplinan, termasuk mengajarkan untuk mengenal lingkungan sejak dini, karena lingkungan memiliki pengaruh yang sangat besar terhadap pertumbuhan dan perkembangan psikologi dan kepribadian anak. ${ }^{3}$

Pertumbuhan dan perkembangan pertama anak usia dini terjadi dalam keluarga, setelah itu lingkungan sekolah baru kemudian di masyarakat. Ayah dan ibu sebagai orang tua dalam keluarga memiliki peran penting dalam keberhasilan perkembangan anak. Orang tua adalah peletak dasar pendidikan, sikap dan keterampilan hidup seperti ibadah, karakter, tata krama, estetika, kasih sayang, keamanan, dasar-dasar mematuhi aturan dan menanamkan kebiasaan.

\footnotetext{
${ }^{1}$ John W. Santrock, Masa Perkembangan Anak, Buku 1 Edisi 11 (Jakarta: Salemba Humanika, n.d.), h. 22.

${ }^{2}$ Anderson, Carolynne Shinn, dan Fullilove Mindy T, "The Effectiveness of Early Childhood Development Programs," American Journal of Preventive Medicine 24 (2003): h. 32.

${ }^{3}$ Ujam Jaenudin, Psikologi Kepribadian (Bandung: CV Pustaka Setia, 2012), h. 74.
} 
Perkembangan sosial emosional anak merupakan faktor yang sangat penting dan perlu perhatian. Selama ini masih banyak orangtua yang mengesampingkan perkembangan emosional anak, yang tanpa disadari ketika perkembangan emosional terhambat, maka perkembangan sosial dapat berpengaruh. Sebagian besar masalah sosial dan emosional dianggap sebagai akibat dari faktor lingkungan seperti pengasuhan yang tidak konsisten, kondisi kehidupan yang penuh tekanan, lingkungan penuh kekerasan dan sebagainya.

Anak dengan masalah perkembangan sosial emosional cenderung memiliki hambatan besar dalam persahabatan, penyesuaian sosial, perilaku dan akademis bila dibandingkan dengan kelompok anak normal. Anak yang mengalami gangguan risiko secara sosial tersisih, pemalu, kesepian dan terisolasi penarikan diri. ${ }^{4}$

\section{Perkembangan Sosial dan Emosi Anak}

Perkembangan sosial dan emosi yang sehat sangatlah penting untuk anak. Hal ini akan menjadikan dirinya mampu bertingkah laku yang pantas, memahami arti hidup, serta mampu melewati dari anak-anak hingga dewasa tanpa kendala apapun. Sementara ketrampilan bersosialisasi adalah kemampuan anak untuk bekerja sama dan bermain dengan orang-orang di sekitarnya. Mampu memberi perhatian terhadap orang dewasa atau guru, dan mampu berpindah dari satu aktivitas ke aktivitas lainnya. Pada prinsipnya membangun ketrampilan sosial emosional adalah mengajari anak untuk memahami dan mengontrol emosinya saat ia menghadapi konflik. ${ }^{5}$

Perkembangan sosial adalah kemampuan berperilaku sesuai dengan tuntutan sosial. Menurut Hurlock, salah satu tugas penting pengembangan anak usia dini adalah mendapatkan

\footnotetext{
${ }^{4}$ Rini Hildayani, Psikologi Perkembangan Anak (Jakarta: Universitas Terbuka, 2011).

5 theAsianparent, "Tahapan Perkembangan Emosi Sosial Batita," theAsianparent Indonesia, 9 November 2014, https://id.theasianparent.com/tahapan-perkembangan-emosi-dan-sosialbatita/2/.
}

Volume 29 Nomor 2 Juli-Desember 2018 
pelatihan dan pengalaman awal yang dibutuhkan untuk menjadi anggota kelompok di akhir masa anak. Jadi, di masa kecil disebut periode pra-kelompok. Dasar untuk sosialisasi diberlakukan dengan meningkatnya hubungan antara anak dan teman mereka dari tahun ke tahun. Anak tidak hanya bermain lebih banyak dengan anak lain, tetapi juga berbicara lebih banyak. Jika seorang anak dapat menciptakan hubungan yang baik dengan orang lain, bahkan jika itu hanya kadang-kadang, maka sikap terhadap kontak sosial akan lebih baik daripada hubungan sosial yang sering tetapi hubungan tersebut tidak baik.

Anak yang lebih memilih berinteraksi dengan manusia daripada benda akan lebih bisa mengembangkan kecakapan sosial. Manfaat yang diperoleh oleh anak dengan peluang untuk hubungan sosial, akan sangat dipengaruhi oleh tingkat kesenangan hubungan sosial sebelumnya. Apa yang umumnya terjadi saat ini adalah bahwa anak lebih memilih kontak sosial dengan kelompok yang sejenis daripada hubungan sosial dengan kelompok lawan jenis. ${ }^{6}$

Sedangkan Emosi adalah perasaan yang ada dalam diri kita, bisa berupa perasaan senang atau tidak senang, perasaan baik atau buruk. Dalam World Book Dictionary, emosi didefinisikan sebagai berbagai perasaan yang kuat. Perasaan benci, takut, marah, cinta, kesenangan, dan kesedihan. Perasaan semacam ini adalah gambaran emosi. Goleman menyatakan bahwa emosi mengacu pada perasaan atau pikiran yang khas, keadaan biologis dan psikologis dan serangkaian kecenderungan untuk bertindak. ${ }^{7}$

Suasana atau lingkungan keluarga yang nyaman, tenang, dan penuh pengertian antara satu sama lain, akan membuat anak berkembang dengan ceria, lincah dan bersemangat, kecerdasan mereka akan berkembang dengan baik. Jika suasana

${ }^{6}$ Elizabeth B. Hurlock, Chiled Development (Tokyo: Mc. Graw Hill. Inc, 1978), h. 250.

${ }^{7}$ D. Goleman, Emotional Intellegence (1995: Jakarta, Gramedia), h. 411. 
menyenangkan terus berlanjut, perkembangan kepribadian anak berusia 6-9 tahun akan tetap positif. Sebaliknya, orang tua atau pengasuh sering mencela, memarahi dan memukul anak-anak, kondisi ini akan menyebabkan perkembangan kepribadian anak menjadi negatif. Dia merasa ibu, ayah atau salah satu dari mereka membenci dirinya, merasa tidak berharga dan takut untuk bergaul dengan orang lain. Ini akan menimbulkan pikiran bahwa orang-orang yang dekat dengannya saja membencinya apalagi orang lain. ${ }^{8}$

\section{Tahap Perkembangan Sosial dan Emosi Anak}

Psikolog dan psikoanalis Erik Erikson membagi perkembangan sosial-emosi dalam 8 tahap. Empat tahun pertama berkaitan dengan perkembangan sosial dan emosi pada usia bayi hingga 12 tahun, dan empat tahun berikutnya pada usia 12 tahun hingga dewasa. ${ }^{9}$

\section{a. Tahap perkembangan I: Harapan (bayi-2 tahun)}

Tahap pertama merupakan tahap bayi untuk belajar mengenai harapan, serta bagaimana orang-orang di sekelilingnya memberi tanggapan (learning trust vs mistrust). Contoh ketika ia menangis, apakah orangtua akan menanggapi dengan memeluk atau malah memberi bentakan. Jika pelukan yang ia terima, maka bayi (batita) akan belajar bahwa harapannya akan dapat terpenuhi. Dan ini akan membuatnya membangun rasa aman dan percaya, yang merupakan dasar optimisme

b. Tahap perkembangan II: Keinginan (18 bulan - 4 tahun)

Pada tahap ini anak akan belajar menghadapi konflik kemandirian vs rasa malu (learning autonomy vs ashamed). Anak adalah peneliti alami. Saat ia bereksplorasi memuaskan rasa ingin tahunya, lingkungan, terutama orang tua akan menanggapi dengan dua hal; mengagumi dan mendorong ia

\footnotetext{
${ }^{8}$ Ahmad Tafsir, Pendidikan Agama Dalam Keluarga (Bandung: PT. Remaja Rosda Karya Offset, 2002), H. 107.

9 theAsianparent, "Tahapan Perkembangan Emosi Sosial Batita." 
terus bereksplorasi atau malah menertawakan, melecehkan, mengkhawatirkan, dan menganggap apa yang dilakukannya mengesalkan. Jika eksplorasinya dianggap mengesalkan, sehingga ia sering mendengar kata, "Jangan, nanti jatuh", "Awas bahaya", "Jangan gitu, bikin malu aja," maka anak akan tumbuh menjadi anak yang peragu, meletakkan keputusan yang terkait dengan dirinya pada orang lain, tidak mandiri, pemalu, dan selalu merasa bersalah.

Menurut Erikson, tahap kedua adalah tahap psiko-sosial kritis. Mulanya mungkin anak akan terlihat seperti pembangkan yang setiap saat selalu memiliki keinginan berbeda dengan kita, orang tuanya. Wajar jika pada awal tahap ini, ibu sering menyebut anak sebagai "the Terrible Twos". Namun, justru inilah awal ia menuju perkembangan psiko-sosial yang lebih matang. Jadi, jika sekarang ibu sering merasa kesal bila melihat tingkah anak usia 2 tahun, bersabarlah. Ia sedang belajar mengekspresikan keinginannya serta melihat bagaimana lingkungan akan menanggapinya.

c. Tahap perkembangan III: Maksud (3 - 6 tahun)

Pada tahap ketiga, anak-anak akan belajar untuk menghadapi emosi ketika maksudnya diterima atau ditolak (initiative vs guilt). Usia 3-6 tahun, adalah masa bermain untuk anak-anak. Ketika ia bermain, secara naluriah terkadang anakanak mengambil inisiatif untuk melakukan atau tidak melakukan sesuatu. Ketika dia mengambil inisiatif, dia akan belajar apakah lingkungan akan merespons dengan baik, atau bahkan diabaikan.

Jika sambutan baik yang ia terima, maka anak akan belajar 3 hal, yaitu:

1. Mampu berimajinasi, mengembangkan ketrampilan melalui bermain aktif, termasuk berfantasi.

2. Mampu bekerjasama bersama teman.

3. Mampu menjadi "pemimpin" dalam permainan, seperti ia menjadi "pengikut" permainan. 
Sebaliknya, ketika inisiatif selalu ditolak, anak akan selalu merasa takut, sangat tergantung pada kelompok, dan tidak berani mengembangkan pikirannya.

\section{d. Tahap perkembangan IV: Kompetensi (5.5 - 12 tahun)}

Tahap ini berkembang pada usia sekolah. Di sini, anak akan belajar bagaimana berkopetensi dalam kelompok, dengan mengembangkan 3 keterampilan sosial, seperti:

1. Bagaimana mematuhi aturan dan hubungannya dengan persahabatan. Misalnya ketika mendapat tugas piket, bagaimana dia akan mengingatkan temannya yang terlambat tanpa menimbulkan konflik, berpartisipasi aktif dalam tugas kelompok, dan sebagainya.

2. Belajar bagaimana bermain dengan struktur dan aturan tertentu. Misalnya, ketika anak aktif berpartisipasi dalam permainan kasti. Di sana ia akan belajar bagaimana menang dengan tetap berpegang pada aturan dan kerja tim.

3. Belajar bagaimana menguasai mata pelajaran di sekolah dan disiplinkan diri untuk mempelajari materi. Jika emosi-sosial seorang anak berkembang dengan baik, percaya dan merasa aman dengan lingkungannya, pandai berinisiatif, maka ia akan memiliki kompetensi yang unggul dalam lingkungan sosialnya. Sebaliknya, seorang anak yang ragu-ragu akan selalu merasa tidak aman, malu, selalu merasa bersalah sampai akhirnya ia menjadi orang yang inferior (kalah)

\section{Pola Perilaku Sosial Anak}

Perilaku sosial adalah kegiatan yang berhubungan dengan orang lain. Kegiatan yang berkaitan dengan orang lain, yang dibutuhkan dalam bersosialisasi agar tingkah laku dapat diterima, belajar memainkan peran sosial yang dapat diterima dan mengembangkan sikap sosial yang layak untuk diterima oleh orang lain.

Secara khusus, Hurlock mengklasifikasikan pola perilaku sosial pada anak ke dalam pola perilaku sebagai berikut, yaitu, meniru, persaingan, kerjasama, simpati, empati, 
dukungan sosial, berbagi dan perilaku yang akrab. Adapun delapan pola perilaku yang dimaksud, yaitu: ${ }^{10}$

1. Meniru, anak usia dini suka meniru perilaku orang lain atau orang tua, saudara kandung, guru, teman sebaya atau orangorang di sekitar mereka. Perilaku meniru anak dapat dianggap wajar dan alamiah karena sebagian besar anak usia dini suka meniru perilaku orang lain di sekitarnya.

2. Persaingan, anak usia dini suka bersaing. Di keluarga, anakanak bersaing dengan saudara atau sepupu mereka untuk mendapatkan pujian dan perhatian dari orang-orang yang ada di rumah. Ketika persaingan di lingkungan sekolah dan teman sebaya, anak-anak akan mencari perhatian guru dengan menunjukkan hasil karyanya atau banyak bertanya untuk membuatnya lebih menonjol daripada teman-teman lainnya.

3. Kerjasama, dimulai pada tahun ketiga akhir anak mulai bermain dengan baik dan bersama temannya dengan membentuk kelompok anak usia dini yang mudah bekerja sama dengan sesama teman, karena anak usia dini suka berganti teman dalam jangka waktu yang lama atau singkat. Simpati, anak mudah bersimpati dengan orang lain karena ketika anak berusia lebih dari tiga tahun semakin banyak kontak bermain dengan teman maka simpati akan cepat berkembang.

5. Empati, sama saja dengan simpatik bisa merasakan keadaan emosional orang lain atau lebih mengembangkan diri untuk membayangkan diri sendiri di tempat orang lain.

6. Dukungan sosial, anak lebih mementingkan dukungan dari teman-temanya dari pada dukungan dari orang tuanya.

7. Membagi, sama saja dengan berbagi. Anak mulai mengetahui bahwa salah satu cara mendapatkan persetujuan sosial yang baik dengan cara berbagi miliknya kepada orang lain termasuk orang tua, sodara, guru, dan teman sebaya.

${ }^{10}$ Ahmad Susanto, Perkembangan anak usia dini: pengantar dalam berbagai aspeknya, Ed.1 (Jakarta: Kencana, 2011), h. 139. 
8. Prilaku Akrab, anak usia dini sering kali berprilaku mengakrapkan diri denngan oang yang baru dikenalnya, ketika mereka merasa nyaman dengan guru atau temanya mereka tidak segan untuk memeluk, merangkul, mau digendong, dan memegang tangan. Banyak tanya untuk membuat suasana semakin akrab.

Menurut Wiyani, menjelaskan jika orang tua atau pendidik membandingkan tingkat pencapaian perkembangan sosial-emosional anak pada usia 5-6 tahun dengan usia sebelumnya, maka akan terlihat bahwa pada usia 5-6 tahun anak lebih matang dalam segala hal. Anak-anak akan lebih percaya diri, punya banyak teman, bisa mengobrol dengan orang dewasa dengan nyaman dan diisi dengan semangat dan antusiasme yang sangat tinggi ketika melakukannya. ${ }^{11}$

Pada usia dini, standar tingkat percapaian perkembangan adalah mampu untuk berinteraksi dengan orang lain dan mulai dapat mematuhi peraturan, dapat mengendalikan emosinya, menunjukan sikap percaya diri, serta dapat menjaga diri sendiri, seperti:

1. Dapat berinteraksi dengan teman sebaya dan orang dewasa, pada usia 5-6 tahun, hubungan yang terjalin dengan teman sebaya akan lebih dalam dan dapat menghabiskan lebih banyak waktu. Teman sebaya adalah anak-anak yang usianya kurang lebih sama dengan anak tersebut. Teman sebaya tidak hanya menjadi teman bermain, tetapi juga menjadi perbandingan di luar keluarga mereka. Melalui teman sebaya, anak mendapatkan umpan balik tentang kemampuan mereka, mempelajari kembali apa yang mereka lakukan, lebih baik atau kurang menurut mereka, di mana hal itu sulit dilakukan di rumah karena saudara kandung biasanya lebih tua atau lebih muda.

${ }^{11}$ Wiyani, Novan Ardy, Mengelola Dan Mengembangkan Kecerdasan Sosial Dan Emosi Anak Usia Dini (Yog: Ar-Ruzz Media, 2014), h. 132. 
2. Dapat menunjukkan kepercayaan diri, sikap positif yang ditunjukkan oleh orang tua atau pendidikan kepada anakanak sangat berpengaruh terhadap perkembangan kepercayaan pada anak usia 5-6 tahun. Memberi hadiah, pujian, pengasuhan yang demokratis, sikap ramah dan tersenyum dari orang tua, orang dewasa di sekitar kediaman atau pendidik adalah sikap positif yang sangat mempengaruhi perkembangan kepercayaan diri anak-anak. Anak-anak berusia 5-6 tahun yang memiliki kepercayaan diri, ditunjukkan oleh enam kemampuan berikut

a. Berani bertanya dan menjawab saat di tanya teman, guru, orang tuanya atau orang dewasa lainnya

b. Mau mengemukakaan pendapat secara sederhana

c. Mengambil keputusan secara sederhana

d. Bermain pura-pura atau bermain peran tentang suatu profesi yang biasanya anak sukai bahkan anak kagumi

e. Bekerja secara mandiri mampu menggunakan pakaian, makan, mandi dan lain-lain sendiri

f. Berani bercerita secara sederhana

3. Dapat menunjukan sikap kemandirian pada usia 5-6 tahun. Anak idealnya sudah bisa mengatur dirinya sendiri misalnya mengenakan dan melepaskan pakaianya sendiri, cuci tangan, membersikan diri di kamar mandi dan bahkan merapikan pakaianya sendiri. Misalnya anak bisa merapikan mainanya sendiri tanpa bantuan orang lain hingga ia mampu merapikan mainannya dengan rapi seperti bentuk semula.

4. Dapat menunjukan emosi yang wajar seperti menangis, tertawa setiap anak mempunyai masalah di dalam rumahnya biasanya akan terbawa sampai di sekolah.

5. Terbiasakan menunjukan sikap kedisiplinan dan menaati peraturan pada anak usia 5-6 tahun.

6. Dapat bertanggung jawab terhadap apa yang telah ia lakukan. 
7. Terbiasa menjaga lingkungan seperti membuang sampah pada tempatnya, mencuci tanganya ketika kotor, membersikan bekas makanya, dan lain-lain.

Faktor yang Mempengaruhi Perkembangan Sosial-Emosi Anak

Anak sebagai individu mengalami perkembangan unik. Selain ada beberapa persamaan umum dalam pola perkembangan yang dialami oleh setiap anak, ada juga perbedaan perkembangan yang dapat terjadi kapan saja. Itu karena perkembangan pada dasarnya adalah proses perubahan yang melibatkan beberapa faktor yang saling mempengaruhi satu sama lain. Faktor-faktor yang dapat mempengaruhi perkembangan sosial dan emosional anak sebagai berikut ${ }^{12}$ :

\section{Keluarga}

Dalam ilmu pendidikan, keluarga menjadi lingkungan pendidikan pertama dan terpenting. Lingkungan keluarga memiliki peran penting dalam perkembangan sosial dan emosi anak di masa depan serta untuk kehidupan selanjutnya yang akan mereka jalani. Lingkungan keluarga inilah anak pertama kali menerima pendidikan dari orang tua mereka atau orang terdekat. Orang tua adalah pendidik bagi mereka, pola asuh, sikap dan perubahan yang melingkupi orang tua memiliki pengaruh besar pada perkembangan sosial dan emosi anak.

Misalnya ketika orangtua menerapkan pola asuh yang sangat keras dalam mendidik. Pola asuh yang sangat keras cenderung memaksa anak untuk selalu mematuhi perintah yang diberikan oleh orang tua mereka. Kebiasaan ini tentu akan membuat anak merasa tertekan, yang pada akhirnya anak akan menutup diri dari pergaulan dengan orang lain. Dan sebaliknya jika orangtua menerapkan pola asuh yang baik, anak akan menjadi sosok yang berpikiran terbuka yang membuatnya lebih mau bergaul dan memiliki jiwa sosial yang tinggi terhadap orang lain.

\footnotetext{
${ }^{12}$ Wiyani, Novan Ardy, h. 44-52.
}

Volume 29 Nomor 2 Juli-Desember 2018 
Status ekonomi dan sosial orang tua juga mempengaruhi perkembangan sosial dan emosional anak. Misalnya anak yang tinggal dilingkungan keluarga yang kurang mampu membuat anak memiliki masalah sosial dan emosional serta memiliki potensi kognitif yang buruk. Kondisi ekonomi orang tua yang buruk juga tentunya sangat berpengaruh pada makanan bergizi bagi anak yang akan menentukan pertumbuhan fisik dan mendukung perkembangan psikologis mereka, termasuk perkembangan sosial dan emosinya.

Kemudian, jika orang tua berstatus janda atau duda baik karena perceraian atau kematian, itu juga akan mempengaruhi perkembangan sosial dan emosional. Anak merasa kurang kasih sayang dan memungkinkan mengalami masalah emosi seperti kurang percaya pada diri sendiri dan secara sosial akan mengalami kesulitan dalam bergaul karena mereka minder.

Orang tua jika memiliki anak tunggal mereka memberikan perhatian lebih kepadanya dan anak cenderung memiliki sifat manja dan kurang bisa bergaul dengan teman sebayanya, suka menarik perhatian orang dewasa dengan cara kekanak-kanakan dan sebagainya. Sementara itu seorang anak yang memiliki banyak saudara kandung orang tuanya akan sibuk membagi perhatian kepada saudara-saudaranya yang lain..

\section{Sekolah}

Sekolah adalah lingkungan kedua bagi anak. Disekolah anak berhubungan dengan pendidik dan teman sebaya. Hubungan antara anak dan pendidik dan anak dengan teman sebaya dapat mempengaruhi perkembangan sosial dan emosi anak. Stimulus diberikan oleh pendidik kepada anak memiliki pengaruh yang tidak sedikit untuk mengoptimalkan perkembangan sosial dan emosional. Pendidik adalah wakil dari orang tua mereka saat berada disekolah. Pola asuh dan perilaku yang ditunjukkan oleh pendidik di depan anak juga dapat mempengaruhi perkembangan sosial dan emosi anak.

Misalnya, jika pendidik dengan mudah melakukan kekerasan, terutama kekerasan fisik terhadap anak, pada saat itu 
anak juga akan menyelesaikan berbagai masalah yang ia alami dengan kekerasan juga karena ia melihat contoh bagaimana menyelesaikan masalah dengan melakukan kekerasan yang dilihat dari gurunya, tentu saja itu dapat menghambat perkembangan sosial dan emosinya.

\section{Teman sebaya}

Teman sebaya adalah hubungan antara individu pada anak atau remaja dengan tingkat usia yang sama dan melibatkan keakraban yang relatif besar dalam kelompok. Jadi, lingkungan teman sebaya ini yang memiliki peran penting bagi anak dapat membedakan perilaku buruk dan mempertajam tingkat kedewasaan dalam dirinya dengan membandingkan antara teman satu dengan lainnya. Perilaku yang ditampilkan oleh teman sebaya juga memiliki kontribusi yang tidak sedikit dalam menentukan perkembangan sosial dan emosional seorang anak. Jika anak dan teman-temannya dapat bermain sesuai aturan, itu dapat mengoptimalkan perkembangan sosal dan emosinya

\section{Penutup}

Demikian artikel singkat tentang perkembangan anak dalam hal kemampuan sosial dan emosional, mulai dari tahap perkembangan, pola perilaku sosial dan faktor-faktor yang mempengaruhi perkembangan sosial dan emosional anak-anak. Semoga dapat memberikan wawasan dan informasi yang berharga bagi orang tua, pengasuh anak, dan pendidik sehingga mereka terus memperhatikan faktor psikologis dan nonpsikologis terhadap proses pertumbuhan dan perkembangan anak-anak sejak usia dini. 


\section{Daftar Pustaka}

Anderson, Carolynne Shinn, dan Fullilove Mindy T. "The Effectiveness of Early Childhood Development Programs." American Journal of Preventive Medicine 24 (2003).

Goleman, D. Emotional Intellegence. 1995: Jakarta, Gramedia.

Hildayani, Rini. Psikologi Perkembangan Anak. Jakarta: Universitas Terbuka, 2011.

Hurlock, Elizabeth B. Chiled Development. Tokyo: Mc. Graw Hill. Inc, 1978.

Jaenudin, Ujam. Psikologi Kepribadian. Bandung: CV Pustaka Setia, 2012.

Susanto, Ahmad. Perkembangan anak usia dini: pengantar dalam berbagai aspeknya. Ed.1.Jakarta: Kencana, 2011.

Tafsir, Ahmad. Pendidikan Agama Dalam Keluarga. Bandung: PT. Remaja Rosda Karya Offset, 2002.

theAsianparent. "Tahapan Perkembangan Emosi Sosial Batita." theAsianparent Indonesia, 9 November 2014. https://id.theasianparent.com/tahapan-perkembanganemosi-dan-sosial-batita/2/.

Wiyani, Novan Ardy. Mengelola Dan Mengembangkan Kecerdasan Sosial Dan Emosi Anak Usia Dini. Yog: ArRuzz Media, 2014. 